studies and work necessary for the successful completion of this project.

As an investigator, Hale did as much as one man could be expected to do. But his scientific activities covered a much wider range. As foreign secretary of the National Academy of Sciences he was active in establishing the National Research Council of the United States, of which he remained honorary chairman until his death. His international work in astronomy began in 1895 with the foundation of the Astrophysical Journal, following upon the publication three years earlier of Astronomy and Astro-Physics.

Then in 1904 at St. Louis came the foundation of the International Solar Union on Hale's initiative. President at its first meeting, he, with Schuster and Arrhenius, was elected on to its first executive committee, remaining a member of it throughout the life of the Union. In 1919 came the formation of the International Research Council with Hale as an active member of the original executive committee ; later he became president for the years 1934-37 of the International Council of Scientific Unions. In the International Astronomical Union formed under the auspices of the Council, Hale was elected president of the Commission of Solar Physics (1919-25).

Honours and awards came to Hale freely from scientific bodies and universities all over the world. To mention only those from Great Britain, they included honorary degrees from Oxford, Cambridge and Manchester, medals from the Royal Institution and the Royal Astronomical Society, of which latter body he was an associate. Foreign membership was given him by the Royal Societies of Edinburgh and Dublin, by the Cambridge Philosophical Society and by the Royal Society, which in 1932 awarded him the Copley Medal, primarily for his work on magnetic fields in the sun.

F. J. M. Stratton.

ANYONE meeting George Ellery Hale must, I think, have felt at once that he was somewhat out of the ordinary run of scientific men. We knew he was a great figure in science, but felt that he could have been equally great at almost anything else. For Nature had not only endowed him with those qualities that make for success in science-a powerful and acute intellect, a reflective mind, imagination, patience and perseverance-but also in ample measure with qualities which make for success in other walks of life-a capacity for forming rapid and accurate judgments of men, of situations, and of plans of action ; a habit of looking to the future, and thinking always in terms of improvements and extensions; a driving-power which was given no rest until it had brought his plans and schemes to fruition; eagerness, enthusiasm, and above all a sympathetic personality of great charm. This great and varied array of talents gained for him the complete confidence of everyone he met, from the highest to the lowest.

I never ceased marvelling at his great knowledge of almost every department of observatory work. $\mathrm{He}$ was not only for many years director of the great observatory which was so largely his own creation, but also had made himself an expert in most of its varied branches; and I know from my own experience how genuinely he could interest himself in other people's scientific work and ideas, and how warmly and sincerely he could give encouragement.

It was a great tragedy that indifferent health so restricted his activities in the latter years of his life- his ever-eager mind and ardent spirit had made too exacting demands on a none too strong body; it is an even more poignant tragedy that he has not lived to see the completion of the great new telescope which will owe so much to his forethought and planning.

J. H. JEANS.

The death of Dr. G. E. Hale, coming at the end of a slow decline of strength such as he has suffered since July 1936, can scarcely be regarded as other than a merciful release from protracted suffering. The sincere sympathy of his very numerous friends goes forth to his wife and family and relatives, and the memory of a very remarkable personality will be widely cherished.

His geniality and his interest in a wide extent of natural knowledge and of art and literature and history made him a very welcome companion.

Hale was in truth a leader not only in his own chosen investigations in solar physics but also in the initiation and furthering of organization of scientific co-operation. By a rare combination of personal qualifications of which he seemed to be entirely unconscious, he achieved early in life recognition of his power to evoke enthusiastic support in developing available resources for the advancement of natural knowledge. In 1890 he had resisted an offer of the director of the Observatory on Mount Hamilton in Califormia, an offer that he should have the use of the Lick refractor during stated hours in the week for the development of his spectroheliograph. Fortunately, through the wise advice of his father, he decided to utilize full time with a 12-in. refractor specially constructed at the expense of his father. After a couple of years of successful observations in the Kenwood Observatory he was called upon to take charge of the new observatory in Wisconsin, where a finished product of the workmanship of Alvan Clark in the form of a 40-inch achromatic objective, which Hale's enthusiasm had induced Mr. C. T. Yerkes to purchase, was to be mounted in the Yerkes Observatory of the University of Chicago.

In 1904, Hale received noble encouragement from the trustees of the Carnegie Institution to found a Solar Observatory in California, and there he began that very notable succession of advances based on experimental trial on relatively small scale and leading to successively increased power of instrumental equipment on novel lines. Aided by funds contributed by the Carnegie Institution, by Miss Snow, by Mr. J. D. Hooker, by the Rockefeller Foundation and probably also by other sources, there arose on Mount Wilson the observatory provided with extensive workshops and physical laboratories and devoted to the intensive study of all branches of astronomy and many branches of physics. 
There, under the stimulating influence of Hale in the encouragement of team work, not only were opportunities of a very unusual kind afforded to the members of the devoted permanent staff, but also welcome was extended to students of recognized authority from all parts of the world, to join in cooperative work.

Even in the resulting activity, Hale himself found time and energy to produce very notable scientific contributions, such as his splendid discovery (based on Zeeman's discovery of the influence of a magnetic field on spectral lines of a gas rendered luminous in such a field) that sunspots were the seats of violent magnetic phenomena and that the sun showed signs of having a general magnetic field, with poles not far removed from the poles of the axis of the sun's rotation. One of his latest achievements was the invention of his beautiful spectrohelioscope for visually studying local changes of short duration in the features of the sun's surface-a study that seems likely to throw light not only on the cosmical origin of terrestrial magnetic storms and of the aurora borealis, but also on certain peculiar phenomena encountered in the reception of wireless signals, which seem to indicate the arrival of external influences (probably of solar origin) in the outer atmosphere of the earth.

Truly Hale was a leader of outstanding ability, and his influence and memory will long be cherished. His many friends will join in a deep regret that it was not given to him to live to see the completion of that huge enterprise of the 200-in. reflector, in the initiation of which he took so deep an interest.

H. F. Newall.

THE most prominent characteristics of Dr. Hale were his whole-hearted devotion to astronomy and his friendship with his colleagues and fellow workers. His invention of the spectroheliograph and spectrohelioscope and his discovery of the magnetic field in sunspots are tributes to his mechanical genius and insight. The two magnificent observatories and the 200-in. telescope are outstanding achievements. But he had also a very catholic interest in the work of his colleagues all over the world, and was always ready to give them help. The Solar Union had Hale for father and, as wittily said by a German astronomer, Schuster for mother. $\mathrm{He}$ attached great value to good fellowship among astronomers, amateur and professional alike, for the advancement of the science.

I shall always remember the times I have met Hale and the complete absence of any superiority or what is vulgarly but expressively called 'side'. The last occasion when I saw him was some seven or eight years ago, when he invited Sir Herbert Jackson, Prof. A. Fowler and me to lunch, and we heard of his project for the 200-in. reflector. Another time he was passing through Edinburgh after a visit to Andrew Carnegie at Skibo Castle, and was hugely delighted at having beaten Andrew at golf and caught a bigger fish. He was a great man, and I, with many more, am proud to have been among his friends.

F. W. Dyson.

\section{Mr. C. Green}

The death of Charles Green, chief inspector of fisheries in the Fisheries Branch of the Department of Agriculture of Eire, on February 9, after a short illness, came as an unexpected shock to his friends.

He was born in 1876, the only son of the Rev. William Spotswood Green, a well-known alpine climber and organizer of deep-sea trawling expeditions, and was educated at St. Edward's School, Oxford. After taking a degree, with a gold medal in natural science, in Trinity College, Dublin, he was, in 1900, appointed a naturalist on the staff of the newly constituted Fisheries Branch, afterwards becoming inspector and, later, chief inspector.

Though his official duties tended to direct his attention more to the legislative and administrative side of fishery affairs, of which his knowledge was extensive and profound, Green kept in close touch with recent biological research, and it was due largely to his insistence that the dictum, laid down by his predecessors, that fishery administration must have an adequate biological basis, continued to receive due official recognition. His loss will be realized most fully by his immediate friends and colleagues, for most of his work was done under the cloak of official anonymity.

Until other claims on his time became more pressing, Green often attended the meetings of the International Council for the Exploration of the Sea, first as an expert on the staff of the British delegation and later as a delegate from the Irish Free State.

$\mathrm{He}$ was for many years an active member of the Council of the Dublin Zoological Gardens, and was elected a vice-president shortly before his death.

G. P. F.

Wre regret to announce the death of Prof. Wladyslaw Grabski at Warsaw on March 1, after a long and painful illness. He had been rector and lecturer at the Polish Agricultural College and was an authority on the economics of agriculture. After the Great War and the liberation of Poland, Prof. Grabski became a prominent statesman, first as Minister of Agriculture and later as Finance Minister. During his period in office, he founded the State Agrarian Bank and also the Bank of Poland. In 1925, Prof. Grabski retired from political life and returned, as principal, to his old college.

WE regret to announce the following deaths :

Mr. Charles Benson, formerly deputy director of the Agricultural Department, Madras, known for his work on Indian cotton and tobacco, on March 5, aged eighty-two years.

Prof. Alfred Fischel, formerly professor of experimental embryology in the University of Vienna and editor of the Zeitschrift für Wissenschaftliche Biologie, aged sixty-nine years.

Prof. Friedrich von Krüger, for many years director of the Department of Physiological Chemistry in the Rostock Institute of Physiology, aged seventy-six years. 